\title{
Whaling Bans - Another Inch Forward
}

\author{
Richard Fitter
}

At this year's International Whaling Commission meeting, where 'horse trading' between whalers and conservationists was again a conspicuous feature, sperm whales got a respite, but at the expense of the North Atlantic fin whales. For the British ngo-s, banded together in Wildlife Link (which includes ffPS), the main disappointment was the failure of all three major proposals to halt whaling altogether. They now look to a future where hunting has been given up for lack of whales to hunt, and whale-watching takes over. A remarkable feature of the meetings was the leadership of the Seychelles Government, which last year succeded in getting the Indian Ocean Sanctuary for whales.

The mills of the deity who watches over the interests of whales grind exceeding slow. This year the International Whaling Commission, meeting at Brighton at the end of July, made only two significant and positive new decisions: to declare an effective zero quota for sperm whales world-wide (the word 'effective ' covers a face-saving proviso for Japan over the North Pacific stock) and to ban completely, for all whales, the brutally cruel cold grenade harpoon as from 1983 - at present it can still be used on minke whales. Both victories were the result of much behind-the-scenes hard work, by the UK along with other conservationist delegations, and not least by the adviser appointed by the UK ngo-s to the official UK delegation, Sir Peter Scott. But, as so often happens, two small continuing quotas, totalling some 400 North Atlantic fin whales had to be sacrificed (to Iceland and Spain) to enable the sperms to be saved in all oceans. The horse-trading element of international whale conservation has been more conspicuous this year than ever before, and occupied many hours of the 32 commissioners' time, both before and after midnight. The Government of the Seychelles deserves great credit for the persistence with which it pursued the blocking of the last loophole for the use of the cold harpoon. It is a pleasure also to be able to commend the governments of Denmark and South Africa for joining the conservation column, along with a whole covey of new conservationist members: India, Jamaica, St Lucia, St Vincent, Costa Rica and Uruguay. 'We want it to be known', said the Jamaican delegate, 'that we are on the side of those who would conserve and protect these magnificent mammals'.

The meeting started hopefully. The UK had at last been persuaded, not least by ffPS and other ngo-s grouped in Wildlife Link, not only to come out with a full-blooded conservationist stance on the grounds of lack of adequate scientific information - it did that last year - but also to act as though it believed in its own policy. This year the IWC's scientists were readier than ever before to admit that the data are too inadequate to allow firm (or often any) recommendations to be made. However, this created a virtual schism in the meeting, between the conservationists who drew the moral that it was not safe to proceed at all, and the whalers, who said there was therefore no scientific reason why they should not go on whaling. So on Day 2 of the six-day meeting 


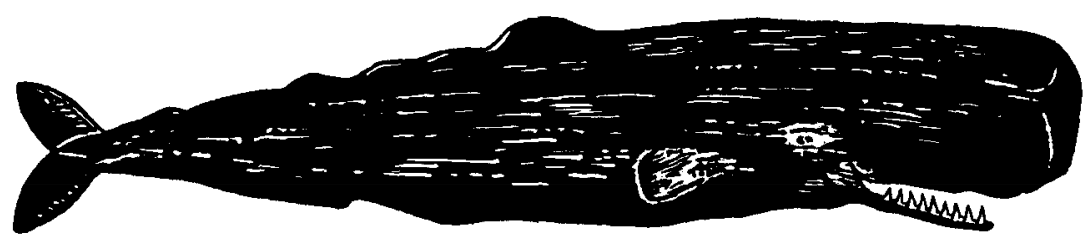

moratoria went down like ninepins. In quick succession the moratorium on all commercial whaling (sought by most of the world since Stockholm in 1972), the world-wide ban on whaling, and the UK's proposed North Atlantic moratorium all just failed to get the $\frac{3}{4}$-majority needed at plenary meetings. Apart from the sperm and cold harpoon bans, little else happened, except the confirmation of zero quotas for protection stocks, or in other words the registration of the failure of the IWC's efforts over the past 34 years. For every protection stock was once a thriving stock of right, blue, humpback, fin or sei whales, able to be harvested for the benefit of mankind. The IWC was set up to maintain this harvest, but has dismally failed, as year after year, often despite scientific advice, it set its quotas too high.

As the whaling industry of the world moves, like Captain Ahab, painfully slowly to its demise, attended by its undertakers, the IWC commissioners, voluntary conservationists are looking ahead. Already we can predict that within a very few years - by 1984? - the non-consumptive uses of whales, in other words whale-watching, will be economically more valuable than the consumptive uses. Indeed great care will be needed to ensure that harassment by whale watchers does not do as much harm to certain stocks, such as the Californian gray and the Argentine southern right whales, as commercial hunters have done. Some international body will be needed to oversee both the increasing number of whale sanctuaries and the increasing volume of benign research on whales - observing living whales not dissecting dead ones. What better body to do this than a revivified International Whaling Commission, its whaling ind ustry function gone? ffPS intends to take the lead in urging the UK Government to pursue the logic of its present admirable stand and promote the conversion of the IWC from an ineffective industry-oriented body to an effective centre of international conservation activity.

The sperm whale drawing is reproduced from Whales by E.J. Slijpe. Hutchinson, 1958.

\section{Conservation Acronyms}

This list is only intended to cover acronyms used in this issue of Oryx.

BSBI Botanical Society of the British Isles CITES Convention on International Trade in Endangered Species

EIS Environmental Impact Statement

FAO Food and Agriculture Organisation

FoE Friends of the Earth

IUCN International Union for Conservation of Nature and Natural Resources

NCC Nature Conservancy Council

NERC Natural Environment Research

Council

ngo non-governmental organisation

NOAA National Oceanic and Atmospheric Administration

RSNC Royal Society for Nature Conservation RSPB Royal Society for the Protection of Birds
SSC Species Survival Commission (of IUCN)

TRAFFIC Trade Records Analysis of Fauna and Flora in Commerce

UNDP United Nations Development Programme

UNEP United Nations Environmental Programme

UNESCO United Nations Educational, Scientific and Cultural Organisation

\section{Clearing $U p$ for the Turtles}

Volunteers from the Fisheries Service and the US Fish and Wildlife Service, led by Dr George Balazs, cleared concrete foundations and metal and wood debris left by the Coast Guard Service on 12-acre East Island, in the Hawaiian National Wildlife Refuge to free the nesting beaches for the green turtles Chelonia mydas. The island is the most important site in Hawaii for these turtles and also a resting place for the endangered monk seal. 